\title{
PERFORMANCE OF A SINGLE SOLAR STILL WITH WATER COOLING OF GLASS COVER
}

\author{
*El-Sheikh, I. H. and **Kishk, S. S.
}

\begin{abstract}
Four identical solar stills were used to evaluate the effect of booting an external water film to cool down the outside glass cover surface. Solar stills were designed, installed and tested at the Agricultural Engineering Department, Faculty of Agriculture, Suez Canal University, Ismailia Governorate, Egypt. The first still was used without cooling as a control. The other three solar stills were supported with a water pump to boost cool water over the glass cover surface and operated for one minute and stopped every 10, 15 and 20 minutes, respectively. The obtained results showed that cooling the outside glass cover increases the stills productivity by 33.2, 20.4 and $12 \%$ for the second, third and fourth solar still, respectively above the solar still without cooling. For the duration of the experimental tests, the hourly average volumetric thermal efficiency was 31.9, 40.4, 41.9 and $43.2 \%$ for the first, second, third and fourth solar still, respectively.
\end{abstract}

\section{INTRODUCTION}

$\mathrm{F}$ Tresh water is required for agricultural and industrials purposes. Direct use of water from sources like rivers, lakes, sea and underground reservoirs are not advisable due to the presence of higher amount of salt and harmful organism. The natural sources can meet a limited demand and this leads to acute shortage of potable water. The solar desalination technology using solar still is cheap and simple process (Malik et al., 1982). The construction of the basin solar still is plausible by denizens in rural areas using the locally available materials. Number of methods is available to improve the productivity of single basin solar stills. The required output from the still is the condensed water from the glass cover. The condensation is higher when the condensing heat transfer from the glass and the evaporation heat transfer from the basin water are high.

*Associate Prof. and **Lecturer of Agric. Eng. Dep., Fac. of Agric., Suez Canal Univ., 41522 Ismailia, Egypt. 
Heat transfer within the solar still depends mainly on the evaporative surface area and the temperature difference between the evaporative surface temperature and the condensing surface temperature (Rai et al., 2013). Lawrence et al. (1990) validated their model by incorporating the effects of water flow over the cover and heat capacity of water mass in the basin. They found an increase of 7 and $10 \%$ in efficiency of solar still due to water flow over the glass cover in the cases with and without black dye present in the basin of the solar still. In order to maximize the existing temperature difference between the water and the condensing surface, an attempt has been made to cool down the condensing surface by flowing water on the condensing surface. The glass cover temperature is reduced by a film of cooling water continuously flowing over the glass (AbuHijleh, 1996). Tarawneh (2007) studied the effect of glass cover cooling on the distillated water productivity. He observed that the glass cover cooling increased temperature difference between the brine water and glass cover as well as increased water productivity. The effect of cooling the glass cover shows an increase on the water productivity with about 17-23\%. The effect of cooling the outer glass surface on the unit productivity was investigated by Abu-Arabi et al. (2002). They found that the cooling of the outer glass surface improved the unit productivity by $30 \%$. Increasing productivity could also be ascribed to faster evaporation from the water surface, at the cover maintaining large temperature difference and improving condensation (Jayaprakash et al., 2012). Ahmed and Alfaylakawi (2012) designed and constructed three identical conventional solar stills to evaluate the effect of implementing an external water sprinkler to cool down the outside glass cover surface. The first still was used without cooling. The second still was used with the water sprinkler operated manually for 30 seconds at 20 minutes intervals. The third still was used with the water sprinkler operated for 30 seconds at 10 minutes intervals. They found that the total daily productivity of the three stills was 3.230, 3.737 and $\quad 4.2591 \mathrm{~m}^{-2}$ day $^{-1}$ respectively. The increase in annual yield is in between 41.3 and $56.5 \%$ with flow of water from the desert cooler, and increase is in between 30.1 and $21.8 \%$ with flow of water at ambient temperature (Somwanshi and Tiwari, 2014). Morad et al. (2015) studied the effect 
of applying cover cooling by water on the distillated water productivity for passive and active stills. The results showed that highest productivity of 6.38 and $7.80 \mathrm{l} \mathrm{m}^{-2}$ day was obtained without and with applying glass cover cooling respectively for passive solar still. While the highest productivity of 8.52 and $10.061 \mathrm{~m}^{-2}$ day was obtained without and with applying glass covers cooling respectively for active solar still. The aim of the present work is to study and evaluate the effect using water flow to cool down the outside surface of the inclined glass cover on the productivity of solar still.

\section{MATERIALS AND METHODS}

\section{Experimental setup}

Four identical single-sloped solar still was designed, installed and tested at the Agricultural Engineering Department, Faculty of Agriculture, Suez Canal University. Ismailia Governorate, Egypt (latitude angle of 30.62 ${ }^{\circ} \mathrm{N}$, Longitude angle of $32.27^{\circ} \mathrm{E}$, and mean altitude above the sea level of $5 \mathrm{~m})$. Solar stills were designed to evaluate the effect of boosting external water to cool down the outside glass cover surface. The geometric characteristics of each still are as follows: width, $0.8 \mathrm{~m}$, length, $1.3 \mathrm{~m}$, still rafter angle, $31^{\circ}$, basin depth, $0.1 \mathrm{~m}$, basin surface area, $1.04 \mathrm{~m}^{2}$ as shown in Fig. (1). The basin of the still is rectangular in shape and made of galvanized iron sheet. It is painted by matt-type black in order to maximize the absorbed solar radiation. A clear glass cover of $3 \mathrm{~mm}$ thick was placed and inclined by a tilt angle of $31^{\circ}$ to transmit the maximum possible of solar radiation flux incident on it. With this inclined angle $\left(31^{\circ}\right)$, the condensates will run down underneath the glass cover into the trough rather than dropping from the cover into the basin. Glass cover has been sealed with silicon rubber which plays an important role to promote efficient operation of condensation as it can accommodate the expansion and contraction between dissimilar materials. To prevent or minimize heat lose from the base and the sides of the galvanized basins, each galvanized basin was fitted inside a wooden frame. The gaps between each wooden and galvanized basin were packed with $0.07 \mathrm{~m}$ thick foam (thermal conductivity $=0.04 \mathrm{Wm}^{-1} \mathrm{~K}^{-1}$ ) for the outside walls and $0.02 \mathrm{~m}$ thick of rock wool (thermal conductivity $=0.0346 \mathrm{Wm}^{-1} \mathrm{~K}^{-1}$ ) for the 
bottom. The cover cooling system consists of a 50 Watt pump connected with plastic tank filled with tap water. The pump was installed to supply water over the cover plate through a perforated plastic pipe installed on the upper part of each solar still to spray water over the glass cover. Open plastic channel with $0.07 \mathrm{~m}$ diameter was installed at the end of the inclined surface to recirculate water from the glass cover to the tank again. The four stills were positioned on a suitable steel structure and faced the south direction. The first still was used without cooling as a control. The second still was used with the pump operated automatically with the aide of a timer for one minute at 10 minute intervals. The third and fourth stills were operated also for one minute but with 15 and 20 minutes intervals, respectively. The flow rate of the cooling water in this study was adjusted at $2.51 \mathrm{~min}^{-1}$ (Rajamanickam and Ragupathy, 2013). The experiments were carried out on $18^{\text {th }}$ August 2015. The experiments were conducted from sunrise to sunset and all the four stills were operated simultaneously.

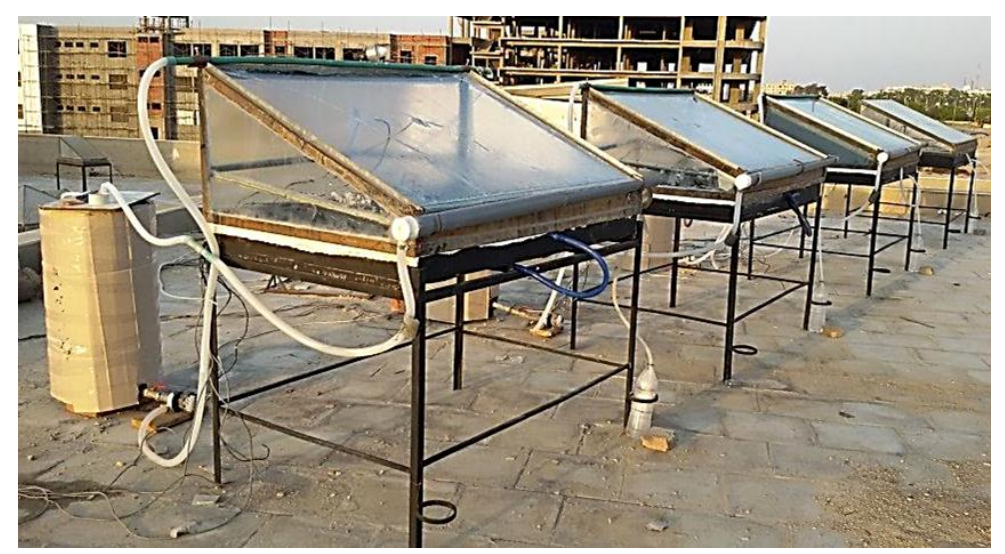

Fig. (1): A photo of the four solar stills with cooling arrangement for glass cover.

\section{Measurements and data acquisition}

All experiments were started at 5.03 to 18.06 local time. The experimental procedure commenced by cleaning dust from the external glass covers and the collected water was measured each hour during 
daylight. Meteorological station (Vantage Pro 2, Davis, USA) located above the roof of the Agricultural Engineering Department was used to measure different macroclimate variables such as solar radiation flux incident on a horizontal surface (pyranometer), dry-bulb, wet-bulb, and dew-point air temperatures. Four thermocouples were used to measure the temperatures of inner surface of glass cover, vapour and water in the basin. These sensors were connected to a data-logger system (Lab-Jack logger, USA) to display and record the data during the experimental period. All thermocouple sensors were calibrated with an electronic thermometer $\left(-10\right.$ up to $\left.100^{\circ} \mathrm{C}\right)$. The output data were recorded every ten minutes for 24 hours per day.

\section{Thermal efficiency of the solar still}

The thermal efficiency of a solar still is defined as the ratio of the rate of heat transfer $\left(\mathrm{q}_{\mathrm{ev}}\right)$ in the still by evaporation-condensation $\left(\mathrm{Wm}^{-2}\right)$ to the solar radiation $(\mathrm{R})$ on the still $\left(\mathrm{Wm}^{-2}\right)$. It can be calculated by the following equation (ASHRAE, 2005; Duffie and Beckman, 2006):

$$
\eta_{\mathrm{vol}}=\frac{q_{e w}}{R}
$$

In practice, there is some loss of produced fresh water back into the basin of the still (by dripping from the glass cover to leakage from collecting troughs). Therefore, the thermal efficiency of the solar still from the experimental measurements (volumetric thermal efficiency) which represents the productivity of fresh water was mainly computed using the following equation (ASHRAE, 2005; Duffie and Beckman, 2006):

$$
\eta_{v o l}=\frac{m_{p} h_{f g}}{3.6 A_{b} R}
$$

where, $\mathrm{m}_{\mathrm{p}}$, is the rate at which distillate of fresh water is produced from the still in $\mathrm{kg} \mathrm{h}^{-1}, \mathrm{~h}_{\mathrm{fg}}$, is the latent heat of vaporization in $\mathrm{kJ} \mathrm{kg}^{-1}, \mathrm{~A}_{\mathrm{b}}$, is the surface area of basin in $\mathrm{m}^{2}$, and $\mathrm{R}$, is the solar radiation flux incident on the basin in $\mathrm{W} \mathrm{m}^{-2}$.

\section{RESULTS AND DISCUSSION}

Through all experimental works, the four fasted solar stills (with and without cooling) were operated appropriately without any malfunction. The effect of flowing external water to cool down the outside glass cover surface on the productivity of solar stills was evaluated. By keeping the 
depth of water in the basin at $2 \mathrm{~cm}$ and with water flow rate $2.51 \mathrm{~min}^{-1}$ (flowing water at ambient). The measurements of solar radiation intensity, various temperatures, and the production of distilled water were taken every hour. Ambient air temperature and solar radiation intensity during $18^{\text {th }}$ of August 2015 are shown in Fig. (2). The intensity of solar radiation gradually increased from sunrise until reaching the maximum value at noon, and then it gradually decreased until reaching the minimum value prior to sunset. It can clearly be seen that, an increase in the solar radiation and ambient air temperature occurred from $182.0 \mathrm{Wm}^{-2}$ and $26.4^{\circ} \mathrm{C}$, respectively till it reached the maximum values of $842.0 \mathrm{Wm}^{-2}$ and $35.2^{\circ} \mathrm{C}$ at $13.00 \mathrm{~h}$. The average intensities of solar radiation were $500.5 \mathrm{Wm}^{-2}$. Also, the average ambient air temperature for the investigated period was $32.1^{\circ} \mathrm{C}$. As the intensity of the solar radiation falling on the four solar stills was increased, the productivity of fresh water increased due to the increase in heat energy gained for saline water vaporization inside the stills.

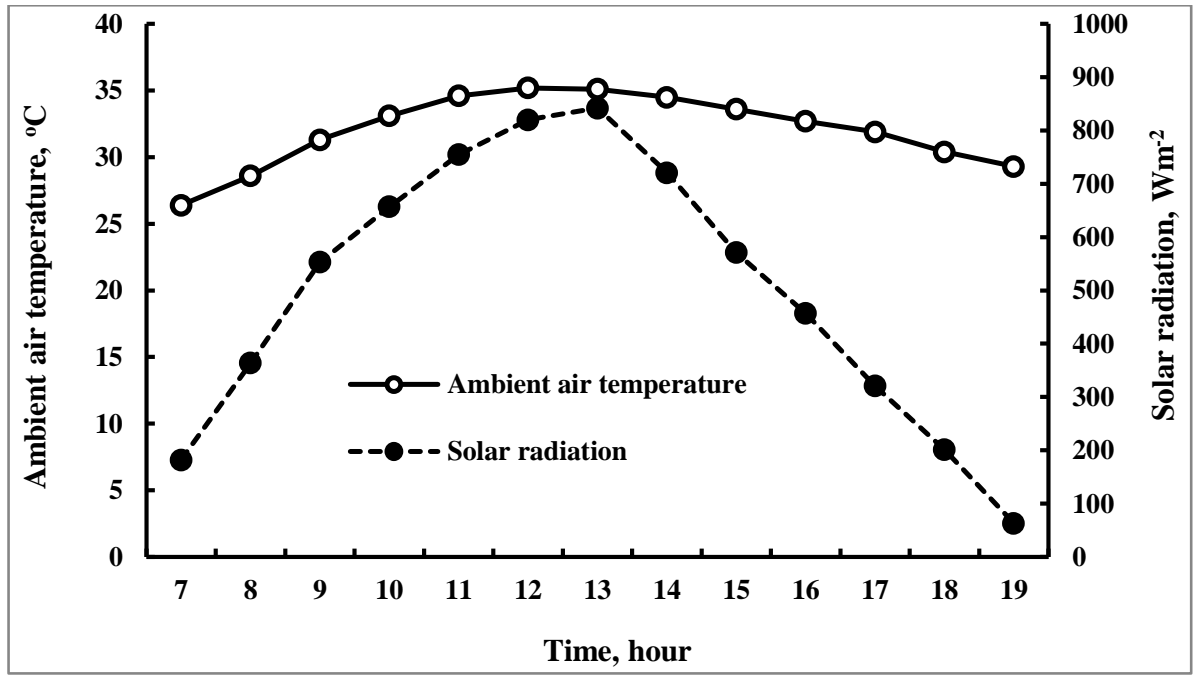

Fig. (2): Average of weather conditions throughout the experimental period for $18^{\text {th }}$ of August 2015.

The variations in temperatures at different locations of four different solar stills are presented in Fig. (3). As shown from the illustration, the temperatures have the same trend, as they increased in the morning hours 
and attain maximum values at around 13:00 $\mathrm{h}$, and decreased in the evening hours. This is obviously due to the fact that the solar incident radiation increased in the morning but decreased in the afternoon. The vapour temperature had the largest temperature because the particles have enough heat energy to evaporate. The highest vapour temperature was obtained between 13:00 pm and 14:00 $\mathrm{h}$ for the all solar stills. It is noticed also that the average vapour temperature were found to be 52.7, 51.3, 51.3 and $51.4^{\circ} \mathrm{C}$ for the first, second, third and fourth solar still, respectively. Fig. (3) compares the hourly temperatures of saline water obtained for single slope solar stills with and without cover cooling. From Fig. 3 it can clearly be seen that saline water temperatures increased for all tested solar stills reached the maximum values of $64.7,63.8,62.8$ and $63.9^{\circ} \mathrm{C}$, for the first, second, third and fourth solar still, respectively in afternoon $(13.00 \mathrm{~h})$ because to the absorbed solar radiation exceed the losses to the surrounding. After $13.00 \mathrm{~h}$, saline water temperature decreased because the heat energy losses from the solar stills which became larger than the absorbed solar radiation. Average saline water temperatures for solar stills around the day with one hour interval were found to be 50.1, 49.9, 49.6 and $49.4^{\circ} \mathrm{C}$ for the first, second, third and fourth solar still, respectively. The water temperature depends on some other parameters such as the intensity of the incident solar radiation, absorptivity of the water and black basin, covering type and solar still air temperature. Also, Fig. (3) shows the effect of boosting cooling water above the glass cover on the inner glass cover temperature. The glass cover temperature decreased with decreasing cooling water interval from 20 minute to 10 minute. At 10 minute intervals, glass temperature distribution was uniform over the surface of the cover plate. It can be also noticed from Fig. (3) that the glass cover temperature was usually lower than that of the water temperature except in the early morning when the difference between them was very small. As the glass cover temperature is much lower than the water vapour temperature, it caused condensation of vapour on the internal surface of the glass. In the early morning hours $(7.00-8.00 \mathrm{~h})$, the glass temperature was close to the water and vapour temperatures resulting in small productivity due to the small heat energy absorbed by the water at these times. 


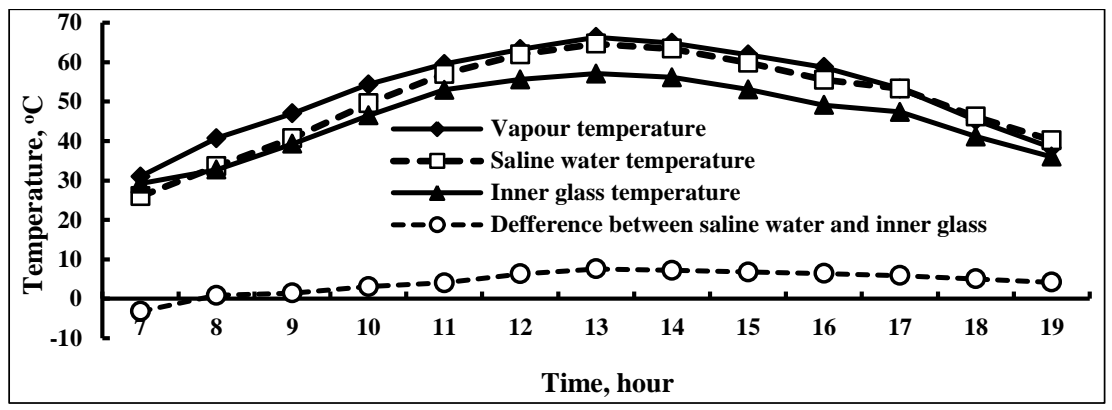

A - Solar still without cooling (first solar still)

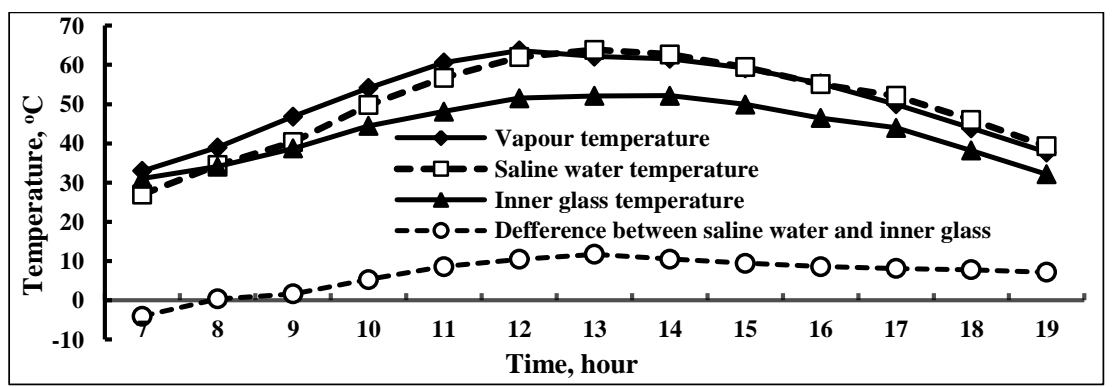

B - Solar still with cooling cover 1 minute at 10 minute intervals (second solar still)

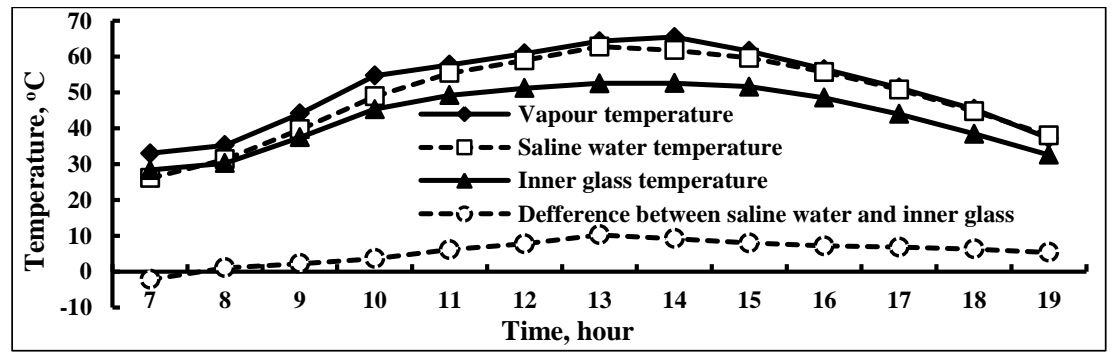

C - Solar still with cooling cover 1 minute at 15 minute intervals (third solar still)

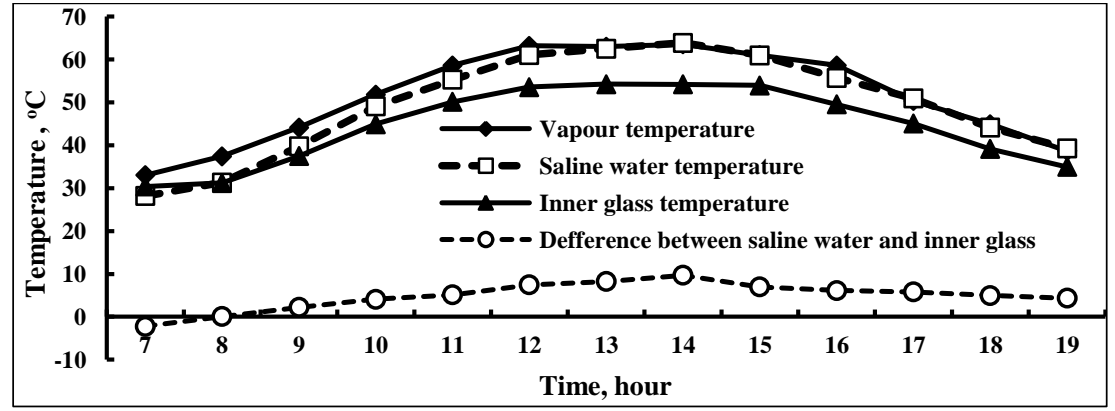

D - Solar still with cooling cover 1 minute at 20 minute intervals (fourth solar still)

Fig. (3): Hourly variation in temperature of solar stills. 
Average inner glass temperatures for solar stills were found to be 45.9, $43.3,44.2$ and $44.8^{\circ} \mathrm{C}$ for the first, second, third and fourth solar still, respectively. It can be seen that the inside glass cover temperature is noticeably higher when experiments were carried out without cooling the cover. The difference in temperature between saline water and inner glass throughout the day for the four different solar stills is plotted also in Fig. (3). It is clear that during early morning glass cover encountered the solar radiation first and its temperature rose very fast compared with the rising in water temperature. As a result the difference becomes negative. These differences remains negative till water temperature exceeded glass temperature. The increase of temperature difference between the saline water and the condensing surface led to a better production. In the case of solar still without the cooling cover the average difference of temperatures between water and glass cover reached $4.2^{\circ} \mathrm{C}$. Meanwhile, cooling of one side of the single slope solar still increased this different to $6.6,5.4,4.6^{\circ} \mathrm{C}$ for the second, third and fourth solar still, respectively. These results corroborate finding by Jayaprakash et al. (2012) and Tarawneh (2007). The largest difference of temperatures of $11.7^{\circ} \mathrm{C}$ was found for the second solar still at $13.00 \mathrm{~h}$. The economical productivity rate of fresh water reflects how much the solar stills were adapted to the cooling treatment. Fig. (4) shows the effect of cooling water flow rate above the glass cover on condensate output. Water cooling can be considered as one of the parameters that has a direct effect on the productivity of fresh water. It can be seen that the productivity of the four solar stills have the same trend, as they gradually increased from early morning till reached the maximum values at afternoon, and that was due to the effect of heat storage. The productivity then decreased with the time of day until reaching the minimum values just prior to sunset time when intensity of solar radiation and ambient air temperature decreased. The maximum distilled yield was 545, 739, 677 and $624 \mathrm{ml}$ at 13:00 $\mathrm{h}$ for the first, second, third and fourth solar still, respectively. This is because the temperature difference between the brackish water and inner surface of glass cover in this time was higher than at other times, which resulted in high freshwater productivity. Whereas, the lowest distilled yield were $13,14,14$ and $12 \mathrm{ml}$ at 8:00 $\mathrm{h}$ for the first, second, third and fourth solar 
still, respectively. This is because the temperature difference between the brackish water and inner surface of glass cover in the early hours of the morning was lower than at other times, which resulted in low freshwater productivity. Average production under the four tested solar stills were found 248, 330, 298 and $277 \mathrm{ml} \mathrm{hr}^{-1}$ for the first, second, third and fourth solar still, respectively. It is obviously noticed that solar still supported with water cooling scenarios improved the productivity compared the solar still without cooling. Using the flow of water over the glass cover of the three stills (second, third and fourth solar still) resulted in an increase in the condensed freshwater rate. Fig. (5) shows the actual cumulative production rate for control and the three different time intervals. The obtained results also showed that applying cover cooling flash tactic for one minute on and 10 minutes off comparing with the other flash tactics provided the height daily performance. The highest productivity of 4.2921 day $^{-1}$ was obtained with applying water cooling for one minute on and 10 minute off. Like the production rate variations, the cumulative production was higher throughout the entire day for the second still which operated for $1 \mathrm{~min}$ at $10 \mathrm{~min}$ intervals. This is due to increasing the temperature difference between the water and glass cover. The daily average productivity of freshwater was found 3.222, 4.292, 3.879 and 3.6071 day $^{-1}$ for the first, second, third and fourth solar still, respectively. These represent an increase in the daily productivity of the three stills which cools the surface of their glass covers by water.

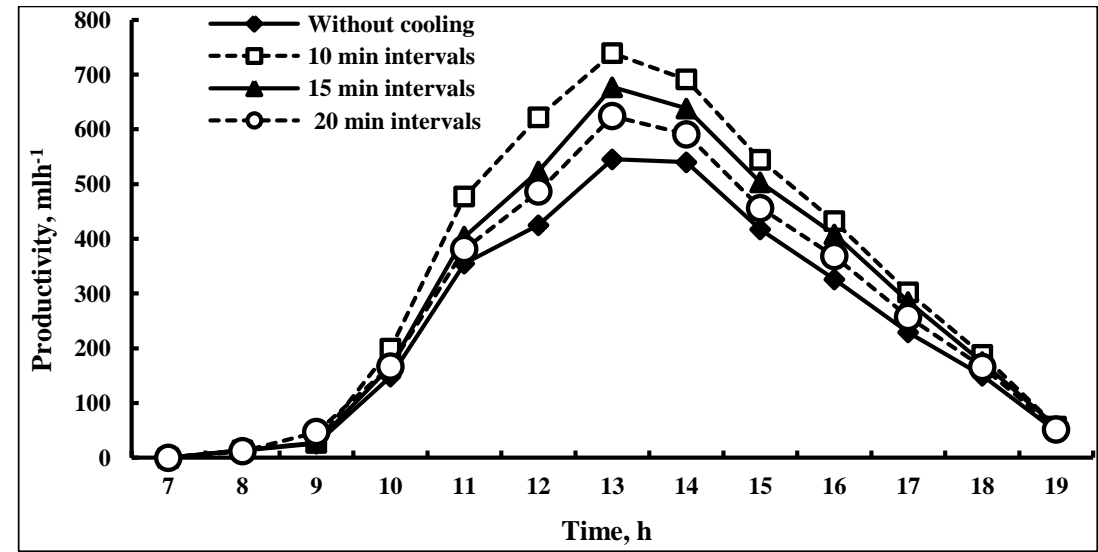

Fig. (4): Hourly distillated water of solar stills with and without cooling glass covers. 


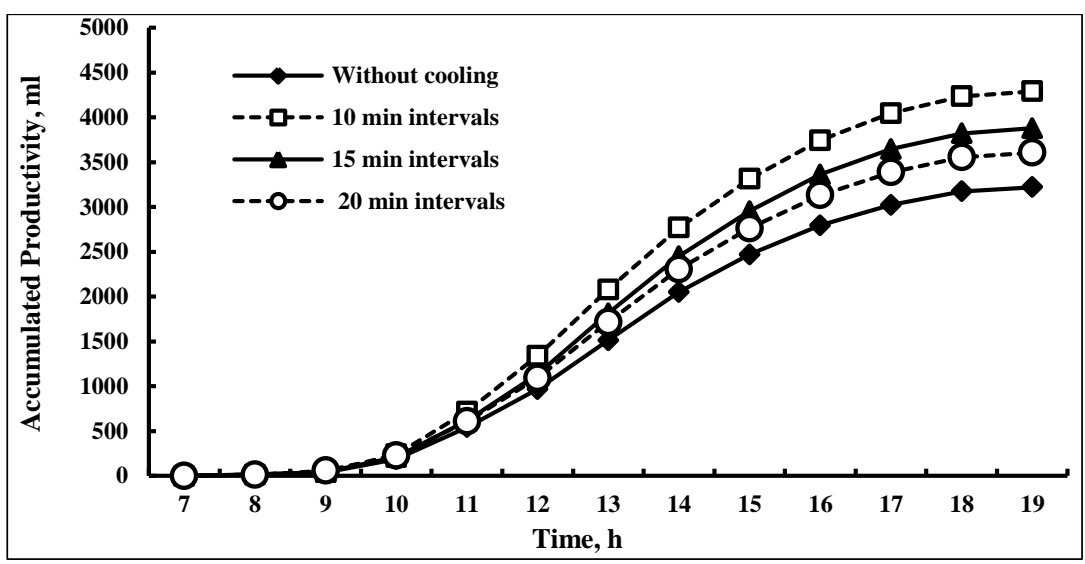

Fig. (5): Effect of water cooling on stills hour accumulated productivity.

Cooling down the outside glass cover of the solar still using water increases the stills productivity by 33.2, 20.4 and $12 \%$ for the second, third and fourth solar still, respectively above solar still without cooling. Similar results were reported by Somwanshi and Tiwari (2014), where they found the yield was increased between 30.1 and $21.8 \%$ with flow of water at ambient temperature. Condensate output increased with decreasing cooling water flow rate from 20 minute off to 10 minute off.

The volumetric thermal efficiency of the solar still is considered the most important factor for evaluation because it can reveal the best solar still operation. Variations of volumetric thermal efficiency of the stills under the average prevailing weather conditions are depicted in Fig. (6). Thermal efficiency of solar stills with cooling scenarios was higher compared with still without cooling. This could be to ascribed better condensation of water vapor at the bottom of glass. The thermal efficiency was low in the morning because the production of flash water, solar intensity and temperature of the saline water in the basin were low at that time. However, in the afternoon, the thermal efficiency was high because the productivity and temperature of the saline water in the basin was high despite the low solar radiation as illustrated in Fig. (6). For the duration of the experimental tests, the hourly average volumetric thermal efficiency were $31.8,41.5,38.2$ and $35.4 \%$ for the first, second, third and fourth solar still, respectively. The results show that the volumetric 
thermal efficiency and productivity of solar still are directly proportional. Similar conclusion was also pointed out by Lawrence et al. (1990).

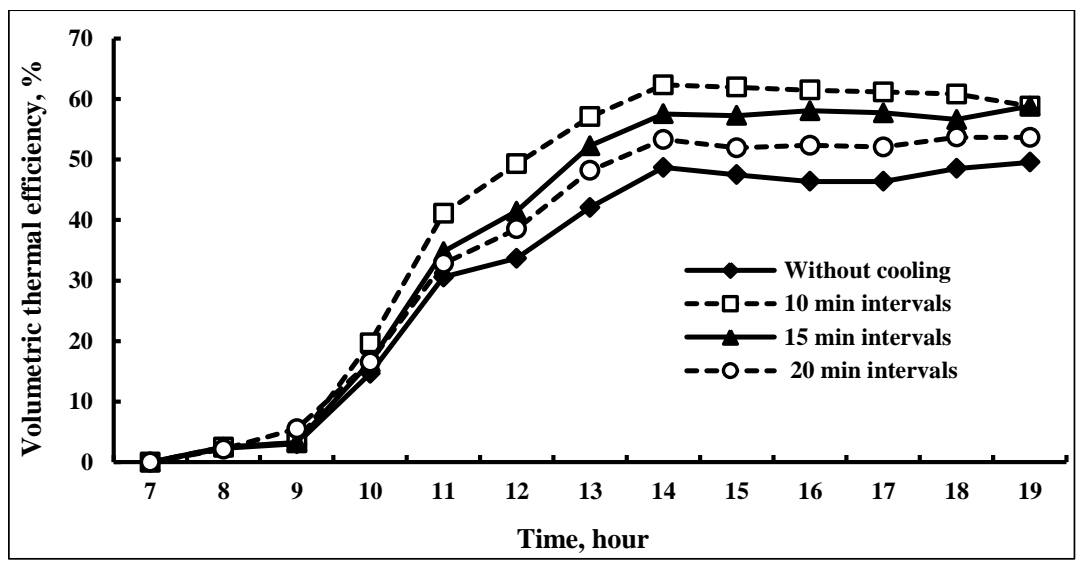

Fig. (6): Volumetric thermal efficiency for solar stills without and with cover cooling

From previous results the highest production and volumetric thermal efficiency were obtained from still operated for 1 minute at 10 minute intervals (the second still). After identifying the best time intervals for stopping flushing cooling water over the cover (10 minute), another experiment was conducted to choose the best operation time. Tree operation durations were tested (1,2 and 3 minutes) at 10 minutes intervals. Thus, four similar stills were used, the first still was used without cooling as a control. The other stills were using a water pump operated automatically at 10 minute intervals for 1,2 and 3 minutes, respectively. In the case of solar still without cover cooling, the difference of temperatures between water and glass cover reached $4.3^{\circ} \mathrm{C}$. Meanwhile, cooling of one side of the single slope solar still increased this average different to $6.1,6.8,7.6^{\circ} \mathrm{C}$ for the second, third and fourth solar still, respectively. The largest difference of temperatures of $13^{\circ} \mathrm{C}$ was achieved for the solar still with cooling operated for 3 minute at 10 minute intervals. The largest temperature differences of $7.4,11.5,12.6$ and $13^{\circ} \mathrm{C}$ for the solar still with cooling $1 \mathrm{~min}$ on $10 \mathrm{~min}$ off, solar still with cooling $2 \mathrm{~min}$ on $10 \mathrm{~min}$ off, solar still with cooling $3 \mathrm{~min}$ on $10 \mathrm{~min}$ off, respectively. The yields $\mathrm{ml} / \mathrm{hr}$ for the different solar still trials is 
shown in Fig. (7). It can be seen that, the productivity of fresh water for the four different solar stills gradually increased from early morning until reached the maximum values in the afternoon then they decreased till approached the minimum values just prior to sunset. The maximum distilled yield was 535, 722, 765 and $801 \mathrm{ml}$ at 13:00 h for the first, second, third and fourth solar still, respectively. Average production under the all solar stills were found 249, 324, 338 and $359 \mathrm{ml} \mathrm{hr}^{-1}$ for the first, second, third and fourth solar still, respectively. Using glass cover water cooling increases the total productivity from $3.2381 \mathrm{day}^{-1}$ (without cover cooling) to $4.2131 \mathrm{day}^{-1}$ (the second still), $4.3891 \mathrm{day}^{-1}$ (the third still) and 4.6701 day $^{-1}$ (the fourth still). This is because the cover cooling insures a good thermal retention, which increases the evaporation rate, combined with decreasing the cover temperature, which increases the condensation rate, hence, increases the distillate output. The percentage increase in the productivity was $30.1,35.5$ and $44.2 \%$ for the second, third and fourth stills, respectively when compared to the first still.

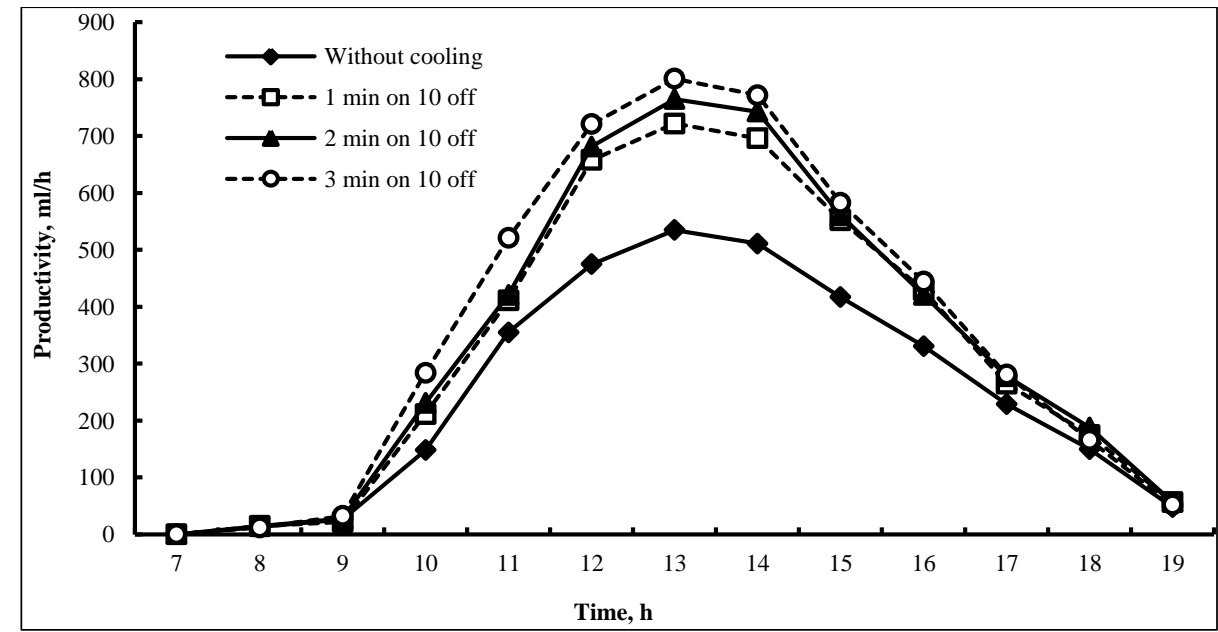

Fig. (7): Volumetric production rate as affected by the solar still water cover cooling treatments as a function of solar time.

Condensate output increase with increasing cover water cooling flow rate from $1 \mathrm{~min}$ on to $3 \mathrm{~min}$. For the duration of the experimental tests, the hourly average volumetric thermal efficiency were 31.9, 40.4, 41.9 and $43.2 \%$ for the first, second, third and fourth solar still, respectively. 


\section{CONCLUSION}

In this present research work, several conclusions can be obtained and drawn as follows:

1- In the case of solar still without cover cooling the difference of temperatures between water and glass cover reached $4.2^{\circ} \mathrm{C}$. Meanwhile, cooling of one side of the single slope solar still increase this different to $6.6,5.4,4.6{ }^{\circ} \mathrm{C}$ for the first, second, third and fourth solar still, respectively.

2- Cooling down the outside glass cover of the solar still using water increases the stills productivity by 33.2, 20.4 and $12 \%$ for the second, third and fourth solar still, respectively above solar still without cooling.

3- For the duration of the experimental tests, the hourly average volumetric thermal efficiency were $31.8,41.5,38.2$ and $35.4 \%$ for the first, second, third and fourth solar still, respectively.

4- Using cooling water over the glass cover increased the total productivity from 3.2381 day $^{-1}$ (without cover cooling) to 4.2131 day $^{-1}$ (with applying water cooling $1 \mathrm{~min}$ ), $4.3891 \mathrm{day}^{-1}$ (with applying water cooling $2 \mathrm{~min}$ ) and 4.6701 day $^{-1}$ (with applying water cooling $3 \mathrm{~min}$ ).

\section{REFERENCES}

Abu-Arabi, M.; Zurigat, Y.; Al-Hinai, H. and Hiddabi, S. (2002) "Modeling and performance analysis of a solar desalination unit with double-glass cover cooling" Desalination, 143, 173-182

Abu-Hijleh, B. A. K. (1996) "Enhanced solar still performance using water film cooling of the glass cover" Desalination, 107, 235 - 244

Ahmed, H. M.; and Alfaylakawi, K. A. (2012) "Productivity Enhancement of Conventional Solar Stills Using Water Sprinklers and Cooling Fan" Journal of Advanced Science and Engineering Research, 2 (3), 168 - 177 
ASHRAE, (2005) "Handbook of Fundamentals" American Society of Heating, Refrigerating and Air Conditioning Engineers, New York, USA

Duffie, J. A.; and Beckman, W. A. (2006) "Solar Engineering of Thermal Processes" New York, N.Y., John Wiley and Sons

Jayaprakash, R.; Arunkumar, T.; Kumar, B.; Sinha, S.; and Mochizuki, H. (2012) "Experimental study on built-in CDS and its comparative analysis with SSSS to produce irrigation quality water in arid regions" Journal of Arid Land Studies, 22 (1), 163 - 166

Lawrence, S. A.; Gupta, S. P.; and Tiwari G. N. (1990) "Effect of heat capacity on the performance of solar still with water flow over the glass cover" Energy Convers. Manag, 30 (3), 277 - 285

Malik, M. A.; Tiwar, G. N.; Kumar, A.; and Sodha, M. S. (1982) "Solar Distillation" Pergamon press, UK

Morad, M. M.; El-Maghawry, H. A. M.; and Wasfy, K. I. (2015) "Improving the double slope solar still performance by using flatplate solar collector and cooling glass cover" Desalination, 373, 1 9

Rai, A. K.; Singh, N.; and Sachan, V. (2013) "Experimental study of a single basin solar still with water cooling of the glass cover" International Journal of Mechanical Engineering \& Technology (IJMET), 4 (2), 1 - 7

Rajamanickam, M. R.; and Ragupathy, A. (2013) "Enhanced performance of a single basin double slope solar still with thin film of water flowing over the cover plate" Journal of Energy Technologies and Policy, 3 (1), 1 - 12

Somwanshi, A.; and Tiwari, A. K. (2014) "Performance enhancement of a single basin solar still with flow of water from an air cooler on the cover" Desalination, 352, 92 - 102

Tarawneh, M. S. K. (2007) "Effect of water depth on the performance evaluation of solar still" Jordan Journal of Mechanical and Industrial Engineering, 1 (1) 23 - 29 


\section{الملخص العربي}

تأثير تبريد السطح الزجاجى بالماء على أداء المقطرات الثمسية

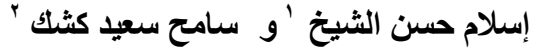

أجري هذا البحث بقسم الهندسة الزر اعية ـ كلية الزر اعة ـ جامعة قناة السويس ويهدف إلي زيادة إنتاجية وكفاءة وحدات تحلية المياه عن طريق تبريد السطح الخـارجى للغطاء الزجاجى بالمـاء.

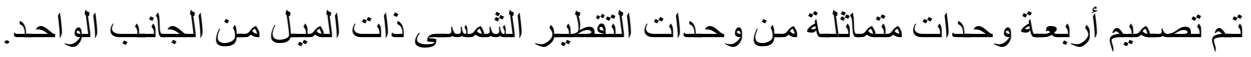

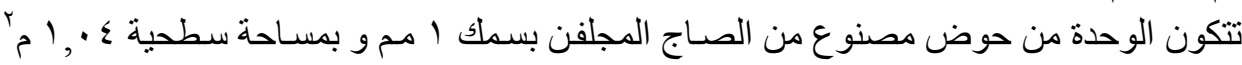

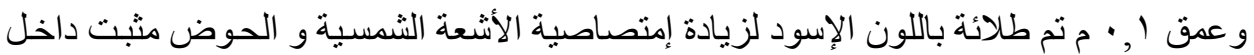

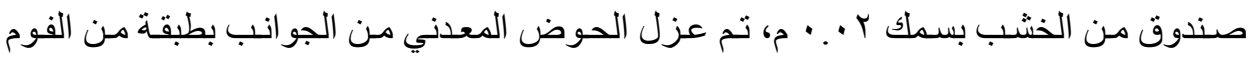

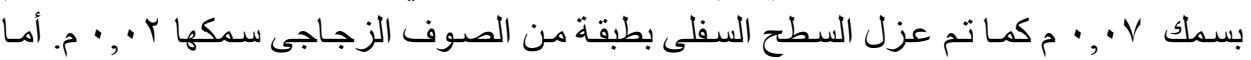
سطح التكثيف الرئيسي فهو عبار عن غطاء من الزجاج الثفاف بسمك ب مم يميل بزاوية مقدار ها

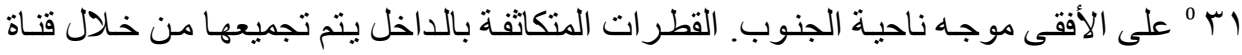
التجميع الموجودة أسفل الغطاء الزجاجى. تم تغذية الوحدات الأربعة بمياه مالحة من قناة السويس.

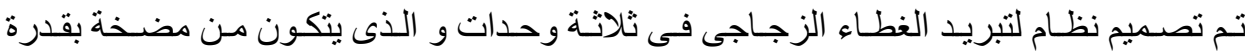

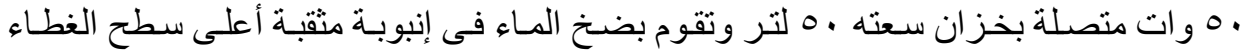

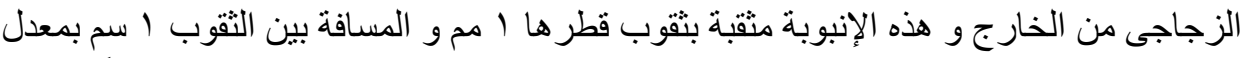

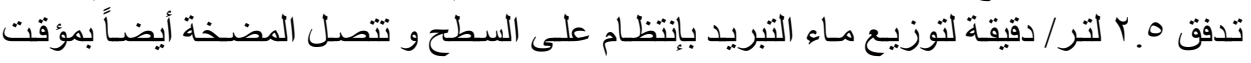

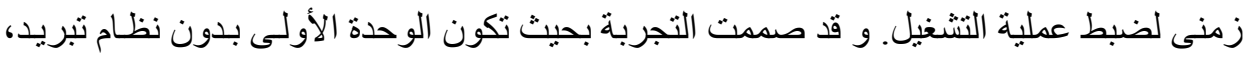

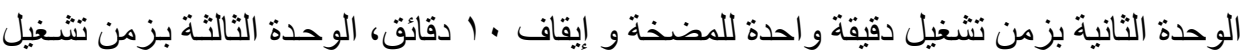

دقيقة و احدة و إيقاف 0 ا دقيقة، الوحدة الر ابعة بزمن تشغيل دقيقة واحدة و إيقاف ـ ب دقيقة.

$$
\text { وقد أوضحت النتائج ما يلي: }
$$

ا ـ متوسط فرق درجات الحرارة بين السطح الداخلى للزجاج و الماء فى الحوض على مدار

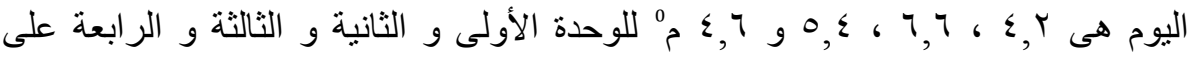
الترتيب.

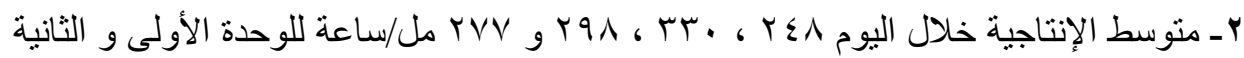
و الثالثة و الرابعة على الترتيب.

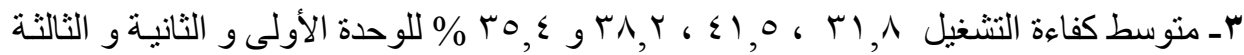
و الر ابعة على الترتيب.

ع ـ فى التجربة الثانية و التى تم فيها تغير زمن تدفق الماء على الغطاء الزجاجى وجى وجد أن إنتاجيـة

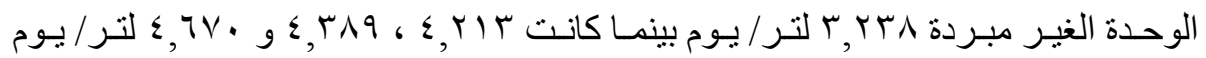

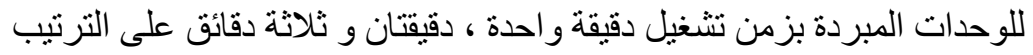

